\title{
The Effects of Technological Innovation on the Competitive Process of Mobile Telephony in the Metropolitan Region of São Paulo
}

\author{
Julian Alexienco Portillo, Álvaro Alves de Moura Jr., Vladimir Fernandes Maciel \\ Economics and Markets Graduate Program, Mackenzie Presbiterian University, São Paulo, Brazil \\ Email: julian.portillo@mackenzista.com.br, alvaro.moura@mackenzie.br, vladimir.maciel@mackenzie.br
}

How to cite this paper: Portillo, J. A., Alves de Moura Jr., Á., \& Maciel, V. F. (2021). The Effects of Technological Innovation on the Competitive Process of Mobile Telephony in the Metropolitan Region of São Paulo. Theoretical Economics Letters, 11, 249-257.

https://doi.org/10.4236/tel.2021.112018

Received: January 27, 2021

Accepted: April 10, 2021

Published: April 13, 2021

Copyright $\odot 2021$ by author(s) and Scientific Research Publishing Inc. This work is licensed under the Creative Commons Attribution International License (CC BY 4.0).

http://creativecommons.org/licenses/by/4.0/

\begin{abstract}
This article aims to present the results obtained from a study seeking to determine whether technological innovation affected the competitive process of the mobile telephony sector in Brazil between 2012 and 2018. To achieve this aim, the panel data technique was used with dependent and independent variables in the cross-section format. The evaluation of the competitive process was carried out considering the impact of the new technologies adopted by the companies in the segment, the prices, and the quality indicators of the service provided on the market share of each operator in the São Paulo region, the largest consumer market in Brazil. The results provide strong evidence that technological innovations in the mobile telephony sector, expressed by the variables of technologies and quality in the provision of services as well as the proxies used for price, affected the competitive process, especially in the strategies for expansion and the loyalty of the customer base.
\end{abstract}

\section{Keywords}

Mobile Telephony, Technological Innovation, Panel Data, Competitive Process, Metropolitan Region of São Paulo

\section{Introduction}

Worldwide, the telecommunications sector has the characteristic of constant technological change. Given this fact, some questions arise concerning the most relevant factors that affect the technological advancement of the sector, how users perceive these innovations, and how telephone operators react to maintain or expand their respective market shares.

The mobile phone sector is characterized, worldwide, by a high degree of con- 
centration and recent significant technological advances. Each technological leap drives the commercialization of new cell phones and phone plans with more resources. Accordingly, the companies that make up the sector need to adapt to the competitive organization that the consumer market brings as feedback for companies, aiming to increase their capacity for innovation as a way to seek new technologies and become more competitive through stimuli and signs of the market and using research and scientific studies as determining factors for technological innovation.

According to Bergo (2015), the structure of the telecommunications market in Brazil is formed by government policies combined with the need for constant technological innovation in the sector. Operators in the segment face dynamic competition, which requires them to earn return rates that compensate for their investments, particularly in R\&D. In addition, companies in the sector deal with the development and implementation of organizational strategies due to the significant increase in the use of new technologies, which consequently bring new services and new ways of communicating.

To assess these issues, this article aims to discuss the competitive conditions of mobile telephone services in Brazil. To this end, the present study is based on the relevant market for services provided in the region of São Paulo and greater São Paulo (with the area code 11). The analysed period started in 2012 when 4G technology was introduced into the country. The evaluation is undertaken through the presentation of data in a panel, using dependent and independent variables in the cross-section format, as the objective is to verify how technological innovation in the mobile phone sector affected the competitive process during the analysed period.

The evaluation of the sector from this perspective shows the importance of the activity for the Brazilian economy, not only because telecommunications affect all other economic activities but also because the sector has undergone significant transformations over the last few years due to a new competitive pattern influenced by both innovations and the regulatory process that has prevailed since the privatization in the segment that has occurred since the 1990s.

According to Sato (2010), the strategies of the companies focus on both the loyalty of the customer base and the search for new subscribers, among them those who did not previously have a cell phone, which turned the market into a competition in the search for customers of the postpaid platform. This loyalty led operators to create several programmes and take retention actions based on loyalty contracts. Besides, sales efforts, such as the promotion of voice and data packages and user incentives, both in price and in the ease of using applications and social networks free of additional charges, have increasingly made the environment among operators more competitive, despite the small number of players. These have contributed to the ease in switching operators for customers, based on number portability.

It is considered that all these competitive strategies can only be effective if op- 
erators make constant investments in innovation as it is a segment in which the quality of the services provided is directly related to technological issues. In this sense, in the mobile phone market, the regulation of economic activities aims not only to promote competition but mainly to increase the level of economic efficiency.

To discuss part of these issues related to the sector, this paper is divided into two parts, in addition to this introduction and conclusions. The first discusses the methodological aspects of the econometric instrument used (data panel) and the variables chosen for the model adopted; and, in the second part, the results of the empirical work performed are presented.

\section{Data and the Model}

The quantitative research approach, according to Sampieri (2006), is one in which data collection and analysis are used to seek answers to research questions. Such an approach is based on the measurement of numbers, counting, and usually the use of statistics to establish the population's behaviour patterns accurately.

In this way, the focus of quantitative research is on the hypothetical-deductive method. A priori hypotheses are put to the test using specific research models. Once the results are aligned with the hypotheses, it can be said that there is definite evidence that corroborates them. If the results are not consistent, the hypotheses can be discarded and plausible explanations and hypotheses should be sought from the results obtained. In this sense, the present work is correlational research, which, according to Sampieri (2006), aims to assess the relationship between more than two concepts, categories, or variables. Thus, the research carried out should assess the relationship between the variables presented.

This work's sample data are composed of variables related to the four largest mobile phone operators in the city of São Paulo with the area code 11 (Vivo, TIM, Oi, and Claro) for the period from 2012 to 2018. The necessary information for this study was extracted from the reports published by the operators about their operational and financial performance and the integration of operations. Data from Anatel, Telebrasil, and Teleco were also collected.

\section{The Model for the Mobile Phone Sector-Greater São Paulo}

To assess the competitive conditions of mobile telephone services in Brazil, from the region of São Paulo and greater São Paulo (with the area code 11) between 2012 and 2018, an econometric analysis was carried out based on the presentation of panel data, using dependent and independent variables in the cross-section format, as the objective is to identify the main variables that affect the sector's competitive process and the elements that emphasize that technological issues are relevant to this process, considering that companies continuously seek to increase and maintain their market share. Accordingly, we started with the equation below: 


$$
y=\beta_{0}+\beta_{1} x_{1}+\beta_{2} x_{2}+\cdots+\beta_{10} x_{10}+\epsilon
$$

The model has the following structure: the variable explained is the market share $(y)$, which represents the size of each operator's share in the mobile market. Moreover, the explanatory variables represent three groups: the first group is composed of variables that are directly related to innovative efforts, expressed by the technologies adopted by the operators; the second group comprises the variables that represent proxies for the price of the mobile telephone services offered by the four operators; and the third group consists of the variables that are indirectly associated with technological efforts, which are the quality indicators. For more details, see Table 1 below.

The technology variables, directly related to the operators' innovation, determine the standard in the cellular network for voice and data communication. Each of the variables indicates a different technology and determines the data connection rate that each supports. For this work, the second-generation technologies 2G (CDMA2000), 3G (WCDMA), and 4G (LTE) were selected.

The 2G CDMA2000 $(\times 1)$ technology supports voice and data traffic up to a rate of $144 \mathrm{Kbits}$ of speed. The 3G WCDMA technology (2) is an evolution of CDMA2000 that adopts a technology in which the user's information is multiplied by pseudo-random codes derived from CDMA, offering a data transfer rate of 256 Kbits. Furthermore, 4G LTE $(\times 3)$ technology is a standard that is also based on WCDMA but focuses only on data traffic.

The variable monthly average revenue $(\times 4)$ refers to the net revenue of each of the operators analysed for the postpaid plan mobile service. The accesses $(\times 5)$ deal with the number of these users of postpaid plans within the region that is the object of the analysis. The ARPU $(\times 6)$, or average data revenue per user,

Table 1. Summary of the variables.

\begin{tabular}{|c|c|c|c|}
\hline Variable & Description & Variable & Description \\
\hline Market share (y) & $\begin{array}{l}\text { Degree of participation of } \\
\text { companies in the mobile } \\
\text { telephony market }\end{array}$ & ARPU $(\times 6)$ & $\begin{array}{l}\text { The average revenue } \\
\text { per cellular data user }\end{array}$ \\
\hline CDMA2000 (×1) & $\begin{array}{l}\text { Technology }(2 \mathrm{G}) \text { for data traffic } \\
\text { on the cellular network with } \\
\text { rates of up to } 144 \mathrm{Kbps}\end{array}$ & $\begin{array}{l}\text { SMP4 call } \\
\text { rate }(\times 7)\end{array}$ & $\begin{array}{l}\text { Quality indicator for } \\
\text { the call completion rate }\end{array}$ \\
\hline WCDMA $(\times 2)$ & $\begin{array}{l}\text { Technology }(3 \mathrm{G}) \text { for data traffic } \\
\text { on the cellular network with } \\
\text { rates of up to } 256 \mathrm{Kbps}\end{array}$ & $\begin{array}{l}\text { SMP8 connection } \\
\text { rate }(\times 8)\end{array}$ & $\begin{array}{c}\text { Data connection rate } \\
\text { quality indicator }\end{array}$ \\
\hline LTE $(\times 3)$ & $\begin{array}{l}\text { Technology ( } 4 \mathrm{G}) \text { for data traffic } \\
\text { on the cellular network with rates } \\
\text { of up to } 100 \mathrm{Mbps} \text { up to } 500 \mathrm{Mbps}\end{array}$ & $\begin{array}{l}\text { SMP10 data } \\
\text { rate }(\times 9)\end{array}$ & $\begin{array}{c}\text { Data transmission rate } \\
\text { guarantee indicator }\end{array}$ \\
\hline $\begin{array}{l}\text { Average monthly } \\
\text { revenue }(\times 4)\end{array}$ & $\begin{array}{l}\text { Net revenue for each } \\
\text { mobile operator }\end{array}$ & $\begin{array}{c}\text { SMP12 self-service } \\
\text { fee }(\times 10)\end{array}$ & $\begin{array}{c}\text { Self-service system } \\
\text { service rate indicator }\end{array}$ \\
\hline Access $(\times 5)$ & $\begin{array}{l}\text { Number of accesses } \\
\text { by postpaid users }\end{array}$ & & \\
\hline
\end{tabular}

Source: Prepared by the authors. 
represents how much revenue each user of the postpaid platform generates for each of the operators.

Finally, the quality indicator variables, which have a close relationship with the technological aspects of the sector, are described. They are linked to the conditions of the services provided, which in turn depend on the technologies adopted by the operators. These indicators are recorded based on surveys carried out by ANATEL as a way of measuring the users' perception of operators.

The call rate indicators SMP4 $(\times 7)$ inform the percentage of voice call completion of the operators. The SMP8 connection rate $(\times 8)$ identifies the success rate of connection to each user's data network on the mobile network. The SMP10 variable $(\times 9)$ reports the instant guaranteed rate at which the user accesses the data network. Lastly, the SMP12 variable $(\times 10)$ is the quality indicator related to mobile operators' self-service system.

\section{Results}

The analysed data counted the operators' observations through a sample of the transversal dimension represented by $i=1,2,3,4$ and the longitudinal dimension represented by the months $t=$ January 2012 to December 2018. The total number of observations in the analysed period was 322. As Wooldridge (2006) pointed out, this panel is characterized as unbalanced, using techniques for short panels, assuming that $\mathrm{T}$ is fixed and $\mathrm{N}$ has enough observations.

To identify the best regression model for the panel data analysis, the Hausman test was used and indicated Prob $>$ chi2 $=0.000$, which means that there is a difference between the random and the fixed methods applied, with the fixed-effect model being the most suitable for application to the model for the analysis, as shown in Table 2.

Table 2 shows the regression with panel data analysis using random and fixed effects. This treatment was necessary to establish the correlation between the special effects not verified in the variables and the fixed effects (Wooldridge, 2006). After the statistical treatment of the fixed effects, the dependent variable market share, concerning the other independent variables of the operators, was submitted to analysis based on the hypotheses of the appropriate research model in such a way that all the observations compare the market share with the technology, revenue, and quality indicators.

It was observed that the LTE technology has a negative relationship with the market share, despite being significant for the model (Table 3). It is understood that the new technologies offered, combined with a strategy of decreasing the average value of revenue for the operator, indicated in the model with a positive relationship with the market, show that the users seek the technology invested in by the operator but for this reason demand a lower price from the service provider.

When analysing the WCDMA technology, even with the highly significant variable, a smaller negative relationship with the market share was apparent. This 
Table 2. Hausman tests.

\begin{tabular}{|c|c|c|c|c|}
\hline \multicolumn{5}{|c|}{ Coefficients } \\
\hline Variables & (b) Fixed & (B). & Difference (b-B) & sqrt (diag(V_b-V_B) ) S.E. \\
\hline LN_LTE & -0.0065556 & -0.008004 & 0.0014484 & 0.00 \\
\hline LN_WCDMA & -0.0517425 & 0.0404007 & -0.0921432 & 0.00 \\
\hline LN_REC_MEN-P & -0.2664174 & 0.6347243 & -0.9011417 & 0.0255354 \\
\hline LN_RECM_ARPU & 0.2964759 & 0.0209311 & 0.2755448 & 0.0271471 \\
\hline LN_TX_CHAM-4 & -0.0638625 & 0.1125085 & -0.176371 & 0.00 \\
\hline LN_TXCONNE-8 & -0.8246712 & -0.2752364 & -0.5494348 & 0.00 \\
\hline LN_GAR_TX-10 & -0.4657976 & -0.7217924 & 0.2559948 & 0.00 \\
\hline LN_TX_ATE-12 & -0.0316934 & -0.0548857 & 0.0231923 & 0.00 \\
\hline \multicolumn{5}{|c|}{$\operatorname{chi} 2(8)=(b-B)^{\prime}\left[\left(V_{-} b-V_{-} B\right)^{\wedge}(-1)\right](b-B)$} \\
\hline \multicolumn{5}{|c|}{$=859.11$} \\
\hline \multicolumn{5}{|c|}{ Prob $>$ chi $2=0.0000$} \\
\hline & $\left(V_{-}\right.$ & - V_B not a d & finite positive) & \\
\hline
\end{tabular}

Source: Prepared by the authors.

Table 3. Random and fixed effects.

\begin{tabular}{|c|c|c|}
\hline EFFECT & RANDOM & FIXED \\
\hline VARIABLES & LN_MKT_SHARE & LN_MKT_SHARE \\
\hline \multirow[t]{2}{*}{ LN_LTE } & $-0.008^{* * *}$ & $-0.007^{* * *}$ \\
\hline & $(0.003)$ & $(0.002)$ \\
\hline \multirow[t]{2}{*}{ LN_WCDMA } & $0.040^{*}$ & $-0.052^{* * *}$ \\
\hline & $(0.024)$ & $(0.018)$ \\
\hline \multirow[t]{2}{*}{ LN_REC_MENSAL_OP } & $0.635^{\star * *}$ & $-0.266^{* * *}$ \\
\hline & $(0.030)$ & $(0.039)$ \\
\hline \multirow[t]{2}{*}{ LN_RECM_ARPU } & 0.021 & $0.296^{\star * *}$ \\
\hline & $(0.047)$ & $(0.054)$ \\
\hline \multirow[t]{2}{*}{ LN_TX_CHAM_SMP4 } & 0.113 & -0.064 \\
\hline & $(0.098)$ & $(0.058)$ \\
\hline \multirow[t]{2}{*}{ LN_TXCONNE_SMP8 } & -0.275 & $-0.825^{\star *}$ \\
\hline & $(0.560)$ & $(0.326)$ \\
\hline \multirow[t]{2}{*}{ LN_GAR_TX_SMP10 } & $-0.722^{\star *}$ & $-0.466^{* * *}$ \\
\hline & $(0.301)$ & $(0.179)$ \\
\hline \multirow[t]{2}{*}{ LN_TX_ATENDESMP12 } & $-0.055^{\star *}$ & $-0.032^{\star}$ \\
\hline & $(0.026)$ & $(0.017)$ \\
\hline \multirow[t]{2}{*}{ Constant } & $-10.833^{* * *}$ & $2.800^{* * *}$ \\
\hline & $(0.390)$ & $(0.614)$ \\
\hline Observations & 322 & 322 \\
\hline R-Square & & 0.304 \\
\hline Number of IDs (i) & 4 & 4 \\
\hline
\end{tabular}

Source: Prepared by the authors. 
shows that older technology attracts a few new users to the operators that offer it. The variable REC_MENSAL_OP is significant in the chosen model; however, it indicates a negative relationship with the operators' market share. It is understood that the operators' monthly revenue decreased within the sample period used along with their participation in the postpaid telephone market. On the other hand, the variable RECM_ARPU has a significant and positive relationship with the market share, which shows that, as the average value (price proxy) paid by the user decreases, there is an increase in the operator's market share, an important point indicating that prices are relevant to consumer decisions.

In the variables of ANATEL's quality indicators, the existence of quite different negative meanings concerning the operators' market share was identified according to the analysis carried out using the econometric model adopted. The call completion rate (variable TX_CHAM_SMP4) indicates how successfully users can make a voice call. As already considered, users have replaced the voice service with the data service, which may explain why this indicator concerning the market share is a variable of little significance. The quality indicator for the user data connectivity rate, the variable TXCONNE_SMP8, also showed a negative sign for the market share, which shows that, as this indicator worsens, the user portability to another operator.

The data connection guarantee fee (GAR_TX_SMP10) was also negative regarding the market share. Despite the negative relationship, the data connection guarantee is better than the connectivity rate. For users, once connected, the data service provides availability for the applications that they use, which depend on the functioning of the technology, preventing the users from changing their operator. Factors such as signal coverage or heavy traffic in the same area or region can cause a slow connection, but the users will remain connected and even able to make voice calls through the data service. In any case, these indicators also express the innovation of services provided by $4 \mathrm{G}$ technology.

The quality indicator of the operators' self-service system (TX_ATENDESMP12) highlighted a negative relationship with deep significance for the market share. It can be seen through ANATEL's measurements that the operators have paid little attention to the users' satisfaction with the service, which can also contribute to the users' portability decisions.

\section{Conclusion}

As can be seen, the innovation of the mobile telephony sector assists in the expansion of the market, the accumulation of capital, the generation of wealth and income, and the widening of the asymmetries between companies, affecting the competitive process, a fact that is characteristic of most economic activities.

In this context, it can be said that, in mobile telephony, the innovation process and its consequent technological changes show that operators are continually changing and that users, based on their consumption needs for goods and ser- 
vices, engage in a constant search for a better quality of service, which leads to fierce competition despite the small number of players on the market.

Given this fact, the present study sought to make a small contribution to the analysis of the mobile phone sector by looking for empirical evidence showing how technological innovation has affected the competitive process among companies in the sector through an analysis that related the market share of the leading operators in the São Paulo region with the technologies adopted (direct impact of innovation), the indicators of revenue (prices), and the quality of services (indirect impact of innovation).

Based on the results of the tests carried out, it was observed that the mobile phone companies acted strategically in the face of innovations in the sector, affecting the competitive process, since the increase in resources introduced by LTE (4G) technology, which enabled a greater data traffic capacity, has driven operators to compete more with each other.

Digital convergence, in which a single data channel is used to transmit or receive any type of information, shows that the mobile phone sector has experienced a paradigm break concerning technology, whereby data transport all the users' information. Another critical point is the relationship between the market and the operators' quality indicators. The call completion indicator, although unfortunate, points to the technical issue that users today communicate more through messages in communication applications than through traditional phone calls. This condition is closely linked to the innovations implemented to meet this new market condition.

When comparing connectivity rate indicators and data connection guarantees, it was observed that the latter have a better relationship, which is explained by the provision of the voice over data service. This technological innovation allows customers to talk to another person through a messaging application, whether by voice, by video, or by text.

Another indicator that has a strong relationship with innovation in the sector refers to the data package contracted by the user with the operator, in which the technology adopted tends to retain customer loyalty by offering a data package that allows free browsing with no additional charges, a fact that is also pointed out by the average revenue per user variable of each operator, ensuring customer retention and maintaining the market share.

Thus, from the analysis carried out in this work, it can be said that innovation has a direct relationship with the market position of mobile operators since it is continually evolving. The perception of users today is that their cell phone is a large part of their day-to-day life, so, if there were no technology, there would not be such a fierce dispute between operators to retain customers or search for new ones.

\section{Conflicts of Interest}

The authors declare no conflicts of interest regarding the publication of this paper. 


\section{References}

Bergo, L. L. (2015). O Setor de Telefonica Móvel: Aspectos da Regulação e da Concorrência na Tutela e Participação do Usuário do Serviço de Telefonia Móvel. Faculdade de Ciências Humanas e Sociais.

Sampieri, R. H. (2006). Metodologia de pesquisa. São Paulo: McGraw-Hill.

Sato, S. K. (2010). As expressões da mobilidade na comunicação das marcas de telefonia celular no Brasil. Tese de Doutorado: Universidade de São Paulo.

Wooldridge, J. M. (2006). Introdução à Econometria. São Paulo: Thomson Learning. 